\section{Pamela Johnson}

Senior Lecturer,

Department of Political

Science and International

Relations, University of

Fort Hare.

Email: pjohnson@ufh.ac.za

DOI: https://dx.doi. org/10.18820/24150509/

JCH44.v1.1

ISSN 0258-2422 (Print)

ISSN 2415-0509 (Online)

Journal for Contemporary

History

2019 44(1):1-25

(c) Creative Commons With Attribution (CC-BY)

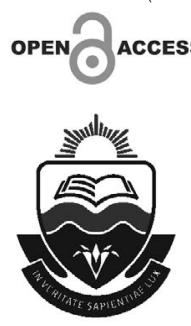

\section{DISSIDENTS AND DISSENTERS: STUDENT RESPONSES TO APARTHEID AT THE UNIVERSITY OF FORT HARE}

\begin{abstract}
As the only university for black students in Southern Africa in the first half of the twentieth century, the University of Fort Hare is the alma mater of prominent African leaders and intellectuals. It is also known for the role played by students in the struggle against the apartheid state that seized control over the university in 1960. However, the common representation of students as unified in resistance belies the fact that the student body was divided, with many reluctant to participate in protests during the apartheid era. These students were named 'dissenters' by the activists - termed 'dissidents' by the author - as they were considered as obstructing the struggle for freedom. Utilising the Gramscian approach to the exercise of hegemony in the form of the reasons for conformity proposed by Joseph Femia, this paper examines the actions and behaviour of both the dissidents and dissenters, based on documents that comprised the personal files of the apartheid era rectors (1960 to 1990). These files contained letters, memoranda and minutes of meetings, notes and telegrams, as well as confiscated student posters and letters from students directed to the rectors. The findings propose that the behaviour of dissenters was based on either the fear of possible repercussions of opposing the apartheid system or the desire not to sacrifice small gains that had been made. This points to the underlying quest for security in a violent and uncertain society.
\end{abstract}

Keywords: hegemony; university; state; dissidents; dissenters; conformity

Sleutelwoorde: hegemonie; universiteit; staat; andersdenkendes; afvalliges; konformisme 


\section{INTRODUCTION}

As a microcosm of society, the university has long been recognised as reflecting the tensions and social dynamics that are present on a wider scale. Notwithstanding its position within society and its role in the reproduction of social classes and values, the university has, by virtue of its intellectual mandate, positioned itself as the source of critique on society and the nature of power.' Because of its prerogative in this respect, in societies such as South Africa during the apartheid era, the state exercised a rigid control over universities, particularly those assigned to the education and training of black students, who were considered by the state to be especially dangerous in terms of their potential to disrupt and to mobilise black society against the state. ${ }^{2}$

The University of Fort Hare, founded specifically to accommodate black students in 1916, is renowned for its role in the struggle against white domination. Established as a college that could offer higher education to 'Natives', it was originally intended as a part of the colonial state's project of domination, which included an element of partial incorporation of the dominated society, in this case, the Xhosa people living in the region. Fort Hare was intended to reproduce members of a middle class of teachers, court interpreters, agriculturalists and administrators, who were envisaged as adopting and reproducing the values and practices transmitted from European society, and in this way contributing to stability. ${ }^{3}$ The 'enlightenment-inspired' activities of the first missionary administration from 1916 to 1959, aligned to religious and liberal ideals, yielded to the direct control exercised by the apartheid state when it assumed control over the university from 1960 to 1990. This phase was marked by vigorous and frequent student contestation so that Fort Hare became symbolic of the internal liberation struggle in South Africa. ${ }^{4}$

Yet, while the relationship between students and the university administration, particularly during the apartheid era, is generally presented as one of confrontation and contestation, research points to differentiated responses that illustrate the nature and effects of cultural hegemony on black society. Despite the sustained rejection of apartheid by the majority of students, there were nonetheless those who resisted calls by student activists for strikes

$1 \quad$ M Mollis, "The paradox of the autonomy of Argentine universities: from liberalism to regulation", in Torres CA \& A Puiggrós, eds., Latin American education: comparative perspectives (Boulder: Westview Press, 1997), pp. 219-223.

$2 \quad H$ Giliomee, The last Afrikaner leaders. A supreme test of power (Cape Town: Tafelberg, 2012), p. 57.

3 L Switzer, Power and resistance in an African society - the Ciskei Xhosa and the making of South Africa (Pietermaritzburg: University of Natal Press, 1993), pp. 7-8.

$4 \quad$ Z Ngwane, "The long conversation: the enduring salience of nineteenth-century missionary/ colonial encounters in post-apartheid South Africa", Interventions. International Journal of Postcolonial Studies, 3(1), 2001, pp. 70-71. 
and protests against the university administration and the apartheid state. The name 'dissenters', applied in a pejorative sense, was conferred by the student activists as a way of indicating that the behaviour of those who were unwilling to join protests was at variance with that of the majority. Student anti-apartheid activists, by way of contrast, will be referred to in this paper as 'dissidents', based on the Gramscian notion of those who resist consent, or conformity, in recognition of their principled stance against the dominant state, its ideology and its practices.

The data on which this paper is based was obtained from the unsorted personal files of the apartheid rectors in the library basement of the University of Fort Hare's Alice campus. These files were almost destroyed when black staff and students drove the white apartheid administration off the campus in 1990 but were fortunately stored by the late Yoli Soul, the first black director of the university library, for future archiving. They remain unsorted in 15 large cardboard boxes through which the researcher sifted. These boxes contain, besides official records and confidential correspondence with government departments and security apparatus, secret dossiers on students and miscellaneous student paraphernalia, such as posters and drawings, alongside letters to the rectors from students and their parents. Among the items rectors collected were posters posted in residences which had been torn down and submitted to the apartheid rectors by campus security, who formed part of the surveillance network of the apartheid administration, serving to reconstruct the scenario in which tensions played out. The university registrar and the library director gave permission to conduct research. They hoped that published research might motivate the university to secure the services of an archivist.

The reliance of this paper on archival sources must be acknowledged and can be considered as problematic in that the information obtained originates from those who held power. In their attempts to root out and eliminate dissent, the senior administrators undertook substantial research in the form of collecting information from security guards who patrolled the campus and lecturers who also served as spies. Thus, much of the documentation on which this paper relies to depict the behaviour of students was either confiscated by the apartheid administration (representing the voice of dissidents) or was written in letters of appreciation to the rector himself (representing the voice of dissenters).

The absence of oral interviews as a source of information is deliberate. On the one hand, oral history is driven by memories that are recognised as 'given to error, misconception, elision, distortion, elaboration and downright fabrication', 5 thus offering prospects for a re-construction of the past that is heavily tinged by

5 C Rassool, "Knowledge and the politics of public pasts", Journal of African Studies, 69(1), 2010, pp. 79-101. 
the present. Much of the narrative around the solidarity of the subaltern in any society - and in this case, black society - is derived from recreating the past to come up with a 'common narrative'6 or 'cannon of experience'7 that illustrates their defiance of the dominant culture.

However, the purpose of this paper is to illustrate a phenomenon that has not been recognised in the copious literature, scholarly and popular, that covers the role of students at Fort Hare in the resistance struggle. Research on student activism at Fort Hare based on oral interviews and written sources foregrounds student solidarity, ${ }^{8}$ and yet data uncovered in the apartheid rectors' files points to a hitherto unrecognised phenomenon of student resistance to participating in actions on campus that were organised against the apartheid administration and the state. This signals the existence of tensions within the student body, although their magnitude is unknown, and these may only have crystallised at particular junctures during student protests and strikes on campus.

No formal interviews were conducted, for the two reasons cited above, and yet numerous conversations over the course of the more than ten years during which I have worked at Fort Hare with colleagues who were students during the 1970s and 1980s depict a closely-knit community on a small and isolated campus that, over and above the studying and socialising that characterises universities around the world, was distinguished by the intensity of political awareness among students. Political activism was prominent relative to white universities, and, as a campus earmarked for serving the needs of the apartheid system, there was universal resistance by students to white domination by the apartheid state. Yet, although participating in the common experience of receiving a university education in an apartheid university gave students a collective sense of identity, this did not translate into unhesitating solidarity when student activists on campus called for mass action against apartheid. The presence of informers in the student body, as well as reluctance to participate for reasons explained later, meant that student unity was more difficult to achieve than is often believed.

In relation to protest during the 1970 s and 1980s, observations by two colleagues present different sides of the spectrum: one stated that to avoid being targeted by activists and subjected to vilification, many students "just followed' during student protests. In her case, her cognisant rejection of the

6 T Moen, "Reflections on the narrative approach", International Journal of Qualitative Methods, 5(4), 2006, pp. 56-69.

7 I Baucom, "Frantz Fanon's radio: solidarity, diaspora, and the tactics of listening", Contemporary Literature, 42(1), 2001, pp. 15-49.

RD Chapman, Student resistance to apartheid at the University of Fort Hare. Freedom now, an academic degree later (Lanham: Lexington Books, 2016); Massey D, Under protest. The rise of student resistance at the University of Fort Hare (Pretoria: UNISA Press, 2010); Z Ngwane, The politics of campus and community in South Africa: an historical historiography of the University of Fort Hare, (PhD thesis, University of Chicago, Chicago, 2001). 
apartheid system did not translate into a principled stance, due to the possible repercussions in the form of expulsion that would sabotage her future and that of the family she was expected to support, as well as the negative connotations of being a rebel in a conservative religious community. On the other side of the spectrum, a colleague who actively participated in cell group discussions on campus and protests against the apartheid administration in the 1980s was blacklisted and found himself unable to secure a job as a teacher after having qualified, while former fellow students were employed at Fort Hare in administrative or lecturing posts. These two instances epitomise the feared and actual consequences of presenting direct resistance to the apartheid state, represented by its many institutions. Another form of resistance in the decision to drop out of university and leave South Africa to go into exile, though it constitutes an extreme form of dissidence, and, ultimately, sacrifice to those who made this choice, is not addressed in this paper.

To the understandable frustration of the dissidents during the apartheid era, the seeming betrayal of the many students they labelled as 'dissenters' lay in their apparent ambiguity of being reluctant to join in protests whilst simultaneously rejecting apartheid. This apparent contradiction lies at the core of this paper and is tackled by utilising a Gramscian conceptualisation of the reasons for conformity in society. This draws on the conceptualisation of reasons for conformity proposed by Joseph Femia, ${ }^{9}$ to be discussed in the next section.

\section{THEORETICAL FRAMEWORK}

The dynamic within the student body will be examined within the context of responses to the state by subaltern groups, according to the Gramscian conceptualisation of the exercise of hegemony. 'Hegemony' is the process whereby the dominant group, through the medium of the state, seeks to consolidate power by eliciting the consent of all groups within civil society to the general values and aims of its hegemonic project. As depicted by Antonio Gramsci, the state is 'the entire complex of the practical and theoretical activities with which the ruling class not only justifies and maintains its domination but manages to win the active consent of those over whom it rules'..$^{10}$ In the execution of the activities aimed at hegemony, the modern state does not rely exclusively on its legal and administrative structures, but it also attempts to elicit consent through a range of activities carried out by institutions, groups and individuals located in civil society who offer intellectual and moral leadership aligned to the state's hegemonic project." Values, beliefs, norms and practices

$9 \quad$ JV Femia, Gramsci's political thought (Oxford: Clarendon Press, 1981).

10 A Gramsci, Selections from the prison notebooks of Antonio Gramsci, edited and translated by Hoare Q \& G Nowell Smith (London: Lawrence and Wishart, 1971), p. 244.

11 R Bocock, Hegemony (Chichester: Tavistock Publications, 1986), p. 85. 
are selectively presented to form a composite of values and expectations that represents the ideal, or the 'way things are'. ${ }^{12}$ Where successful, subaltern groups become assimilated into a way of life, accepting certain beliefs and practices that then serve as a self-perpetuating mechanism in the exercise of hegemony, albeit that this is often manifest in contradictory and ambiguous behaviour of subaltern groups in relation to those exercising power. ${ }^{13}$

However, the state is not always successful in its attempts to incorporate subaltern groups, hence the simultaneous existence of consent and dissent within society. In the case of the apartheid state, there was widespread dissent within black society, countered by state recourse to its coercive mechanisms of the police, legal system and the army. Nonetheless, the existence of 'dissenters' on the Fort Hare campus, in reality, those students who would not join forces with the dissidents who opposed apartheid, appears to suggest the existence of a degree of consent within the student body. At a superficial level, the inclination would be to accept this phenomenon as the manifestation of contradictory behaviour on the part of the subaltern, the outcome of the fallible 'common sense' that Gramsci envisaged as a contradictory and inconsistent composite of values, beliefs, hopes and ideals existing in the minds of all members of society, informing their various thoughts and actions. ${ }^{14}$ The transferal of values originating within the dominant class to the 'common sense' of members of the subaltern fosters the exercise of hegemony by preventing reasoning from taking place in such a way that perfect understanding of the real nature of domination occurs.

However, in another way of considering the apparent contradiction between beliefs and behaviour by focusing on the reasons for conformity, this study draws on those offered by Femia as explanations for the behaviour of the subaltern. These are, firstly, conscious agreement with the fundamental principles offered; secondly, the absence of reflection on these; thirdly, duress, or the experience of coercion; and fourthly, expectations of reciprocity. ${ }^{15}$ The last two, in particular, will be proposed as possible underlying reasons for the apparent conformity of the dissenters at Fort Hare during the apartheid era.

\section{FORT HARE AS AN APARTHEID UNIVERSITY}

The goal of the apartheid era Fort Hare, as articulated by the administration, was to provide 'adequate and effective university training for the Bantu and more specifically the Xhosa ethnic group, and in this manner to contribute materially

\footnotetext{
12 R Williams, Problems in materialism and culture (London: New Left Books, 1980), pp. 38-39.

13 TJ Jackson Lears, "The concept of cultural hegemony: problems and possibilities", The American Historical Review, 90(3), June 1985, p. 580.

14 Gramsci, p. 333.

15 Femia, pp. 38-43.
} 
to the development of the community concerned'. ${ }^{16}$ The narrow, instrumental focus of this mandate was aimed at the training of future administrators and civil servants in an independent Ciskei state that formed part of the greater apartheid scheme. This aim nonetheless incorporated the notion that the university should nurture ideological consent - or conformity - among black students from Xhosa-speaking backgrounds, eliciting their participation within the overarching apartheid plan of ethnically based segregation and separate 'homelands' for different ethnic groups.

There is no doubt that the overwhelming response by black students to the apartheid project was rejection and they were from the outset openly hostile to the apartheid administration installed by the state in 1960. The first apartheidera rector, Johannes Jacobus Ross, encountered student hostility on his first visit to the campus at the end of 1959 before he assumed office. ${ }^{17}$ This was a taste of what was to follow, with the first student strike occurring after Ross and the senate, consisting almost entirely of pro-apartheid white Afrikaner academic staff, refused to allow the formation of a Student Representative Council (SRC) with a new constitution recognising the rights of students. Both Ross and his successor in 1968, Johannes Marthinus de Wet, were members of the secret Afrikaner society promoting the interests of white Afrikaner nationalism, the Broederbond (brotherhood). This society nurtured an obsessive paranoia around the threat of communist infiltration, which was considered as one of the biggest threats to the existence of the Afrikaner nation..$^{18} \mathrm{~A}$ more detailed discussion of the strategy of the Broederbond in relation to universities for black students, in particular, Fort Hare, and the role of the apartheid rectors in pursuing this is to be found in another article by this author. ${ }^{19} \mathrm{~A}$ more detailed discussion of the events that occurred in each decade between 1960 and 1990, as well as the national context and the particular nature of domination exercised by each of the three apartheid-era rectors, is also to be found in the same article. This paper focuses instead on the manifestation of conformity on campus, positing reasons that explain this, according to a Gramscian analysis.

Shortly after coming to power in 1948 to pursue its project of racial and ethnic separation for the preservation of a white Afrikaner nation, the National Party had banned the South African Communist Party, signifying what was construed as the greatest ideological threat to its Afrikaner nationalist ideals. ${ }^{20}$

16 De Wet files (Howard Pim Library, Alice), Academic autonomy of the University of Fort Hare brochure, 1970.

17 D Massey, Under protest, pp. 159160.

18 JHP Serfontein, Brotherhood of power. An exposé of the secret Afrikaner Broederbond (London: Rex Collings, 1979), p. 81.

19 P Johnson, "Brothers in arms: the role of Broederbond rectors in the exercise of hegemony at the University of Fort Hare 1960-1981", Politeia, 37(1), 2018, pp. 1-9. Giliomee, pp. 54-55. 
As a consequence of these fears, the state security apparatus extended throughout civil society, and black universities were considered particularly vulnerable to infiltration by undesirable ideological influences. Ross established close links with the state security police to cultivate a network of secret informers within the student body to provide information about the activities of dissidents on campus.

In the early 1960s, vigorous state repression had seen the arrest of Nelson Mandela and other leaders and the banning of the African National Congress (ANC) and Pan-African Congress (PAC), driving these organisations underground. The first apartheid-era rector's term of office in the 1960 s coincided with ruthless suppression of political resistance by the state and the imprisonment of black political leaders of the ANC and PAC. ${ }^{21}$ This strategy was carried out at every level, including university campuses. The first instance of violent insurrection took the form of a petrol bomb thrown into a lecturer's house at the neighbouring Lovedale College in 1962. A Fort Hare student involved was charged with sabotage and sentenced to five years in prison, with an additional three years for participating in ANC activities.

In 1963, Fort Hare mathematics lecturer Andrew Masondo was arrested with students from Lovedale College and Fort Hare and charged with sabotage for attempting to saw down two electric pylons near Alice. The students were sentenced to prison terms of between eight and fifteen years, while another two Fort Hare students accused of participating in PAC activities were sentenced to six years' imprisonment each.22 In 1964, four students, MS Choabi, SP Gawe, EZ Dladla and AM Saule, were detained under the 90-day clause of the Prevention of Terrorism Act that allowed for detention without charges being laid or those detained going to trial. ${ }^{23}$ According to the personal notes of the first apartheid registrar, HJ du Preez, this was the outcome of a purge of the student body by the security police after one student had turned state witness, leading to their eventual sentencing to between one and three years' imprisonment. ${ }^{24}$ The $1960 \mathrm{~s}$ thus marked the onset of a system of campus vigilance by informers consisting of both staff and students, which was to effectively sow mistrust within the student body, fostering the tension between the dissidents and those accused of 'dissent', as will be shown.

As a consequence of increased vigilance under the Ross regime, the clandestine nature that student dissent had assumed after the ANC Youth League

$21 \quad$ Giliomee, p. 75.

22 De Wet files, HJ Du Preez, "Herinneringe van my twaalf-jarige verbintenis met die Universiteit van Fort Hare as Registrateur 1 September 1959 - 31.8.1971". Unpublished handwritten notes, pp. 31-34.

23 Minutes of the meeting of the Advisory Council, 23 February 1965, cited in Lamprecht JA, Some Basic Trends in Student Unrest - A Report, 1984.

24 Du Preez, pp. 29-31. 
was banned on campus at the end of 1949 - by the missionary administration - intensified. During the apartheid era, cell groups operated to foster discussion on Marxism, banned by the apartheid state, and to organise acts of resistance linked to groups off campus in civil society. The apartheid-era rectors were aware of these, and indeed frequently blamed student protest on external influences, typified in the report on the student boycott of lectures in May 1961. Minutes of the meeting of the advisory council, a parallel structure to the university council that lacked authority and whose members were drawn from black civil society, comprising 'Bantu educationists, businessmen and ministers of religion' - though this translated to chiefs, who formed a substantial component - illustrated the conviction that 'there has all along been a minority group which has been inspired and encouraged by outside sources'. ${ }^{25}$

For the remainder of Ross's term in office, students appeared to be subdued. This semblance of calm was not simply the result of the harsh prison sentences handed out but to the effectiveness of the system of campus spies, which operated in tandem with the police, who, according to Du Preez, performed an outstanding role in preventing communist influences from infiltrating the campus. ${ }^{26}$

Nonetheless, behind the scenes, secret cell meeting's continued among students and contact with external groups was maintained and intensified.

\subsection{The decades of defiance}

After Ross retired in 1968, his successor, Marthinus Jacobus de Wet took office, just as Black Consciousness was emerging as a strong oppositional political force. In that same year, the South African Student Organisation (SASO) was founded. De Wet's aim was to prove that the apartheid system would modernise and lead to the development of black homelands and black people according to their diverse ethnical backgrounds and cultural contexts. However, Black Consciousness was embedded in SASO, which articulated, organised and coordinated student protest across black university campuses in the 1970s, leading to more strident and coherent protest on a national level. Also founded in the 1970s, the Black People's Convention (BPC) and the Black Consciousness Movement invoked solidarity among black people, yet, confronted with an antithetical groundswell emanating from black civil society, De Wet remained steadfast in his apartheid mission.

De Wet's tenure coincided with the period in which the apartheid state intensified its repressive activities: there was an escalation of surveillance activities by the police's Special Branch and an increasing military presence in urban areas. In this context of the exercise of coercion, although De Wet enjoyed

25 Minutes of the meeting of the Advisory Council, 9 June 1961, cited in Lamprecht JA, Some Basic Trends in Student Unrest - A Report, 1984. 
the support of most white staff, whose conformity was based on an agreement with the principles of apartheid or gains derived from the system, presented by Femia as two of four possible reasons for conformity, ${ }^{27}$ he encountered enormous resistance from students.

Barely a month after De Wet was instated as rector, students asked him for permission to allow a branch of the United Christian Movement (UCM), a non-racial organisation, to be formed on campus. His predecessor, Ross, and the registrar, Du Preez, had kept a wary eye on the organisation's activities, having been alerted by the first issue of the UCM's bulletin proclaiming:

[C]ontact, criticism, courage - these are the three elements that are necessary for the creation of a genuine revolutionary movement among South African students ... if the UCM is to be of any use at all it must be totally committed to student revolution. ${ }^{28}$

De Wet thus rejected the request, to which students responded by striking and boycotting classes, demanding that he attend a mass meeting with them. Instead, De Wet followed the precedent that had been set by Ross after the first student boycott of lectures in September 1960, of obtaining the consent of the senate, the council and the advisory council to expel 294 students - almost two-thirds of the student body - from campus in September. Three weeks later, 273 were readmitted and 21 were refused re-admission, though they were allowed to write final examinations. ${ }^{29}$ Each student applicant was vetted by the security police before being re-admitted, and recommendations were made to De Wet.

This process of expulsion and readmission was to become an established pattern in the decades to follow, with security police involvement in admission and selection processes, as well as readmission subsequent to mass expulsions. Background information was provided by the security police, the Special Branch, about students who were identified as undesirable for admission or readmission. Details on their political affliation and information on the activities of their families were supplied, as well as records of meetings they had attended and membership of religious organisations, which were becoming more outspoken in their criticisms of apartheid and their opposition to the state. The extent of surveillance in an era that predated technological devices for gathering information was indicative of the extent to which civil society was infiltrated by spies who were paid stipends for passing information to the security police.

Letters from informers in civil society were kept alongside security police reports in De Wet's dossier. An example is a signed letter from a Guguletu school principal contained in De Wet's 1972 files stating that he did not support 
the application of a certain Mr Sidika because he was a member of SASO. 30 The South African Student Organisation was a radical black student organisation founded in 1968 which articulated, organised and coordinated student protest across black university campuses in the 1970s. Without an SRC on campus, student organisation and protest took place under the auspices of SASO, fortified by the Black Consciousness Movement that had emerged in the 1960s in the wake of the banning of the ANC and PAC. The effectiveness of SASO is exemplified in an undated letter signed 'Soul-searching and Looking Ahead' that urged a boycott of the University of Fort Hare autonomy celebrations, saying,

to be a student - a scholar - does not mean to be blind about other things but books, but to be a man. It is not some conformist act which makes a true student but participation in the struggle against mental blockout. ${ }^{31}$

The anonymous author referred to the 'tardiness, apathy, noncommitment and outright opposition'32 in the student body, an attitude that was later to be dealt with by forcing students to participate in acts of student protest.

In a similar vein, a letter from 'Morally Concerned' lamented the disbandment of the SRC ten years previously and its replacement by a Cultural Committee, drawing attention to the promotion of ethnicism, saying, "the trumpet summons [...] I leave [sic] beyond the bonds of sectionalism: I'm neither a MTEMBU nor a VERKRAMPT', 33 and calling for action against the 'common enemies of men: Tyranny, Dissention and Oppression'34 through a united stand by the student body views.

In 1972, widespread demonstrations against Bantu Education and apartheid, in general, were triggered by the expulsion of SASO leader Onkgopotse Abram Tiro from the Turfloop campus of the University of the North. Student boycotts of classes were followed by a warning from De Wet on 30 May that the senate had resolved that no legal or disciplinary action would be taken against students and all tests would be re-scheduled. The rejoinder to this overture was a long statement from students, encompassing several issues, including the condemnation of apartheid and Fort Hare as part of the oppression, accusing white staff of being racist and objecting to the use of the word 'Bantu' and the use of Afrikaans as a medium of instruction. Black staff were condemned 'for allowing themselves to be used as pawns to dilibitate [sic] the success of a joint cause and

$30 \quad$ De Wet files, Hertoelating dossier, Letter from Mr Ndandani, 1972.

31 De Wet files, Letter from 'Soul-searching and Looking Ahead', 1970.

32 Ibid.

33 De Wet files, Letter from 'Morally Concerned' dated 24 March 1970. 'Mtembu' denotes an ethnic identity that the writer of the note rejects, and 'verkrampt' refers to the narrow-minded, extremely conservative political views of the Afrikaner apartheid regime. De Wet files, Letter from 'Morally Concerned' 24 March 1970. 
thus selling out the Black community', as were students who participated in the system 'with the belief they have something to lose [sic] in this apartheid-based Bantu institution of so-called Higher learning'. The statement ended with a call for students 'to leave this Tribal University, to struggle all our lives until this corrupt Bantu Education is changed and Education is free for all'.35

The subsequent campus protest culminated in the expulsion of 333 students, the largest number of students to have been sent home. ${ }^{36}$ De Wet blamed student protest on the fact that

a group of persons outside the University ... with political and other sinister motives in mind. I cannot but regard these persons as enemies of the Black people, because by their actions they have ruined the academic careers of hundreds of Black students, at a time when the services of these students are indispensable to their development'. ${ }^{37}$

As a consequence, he aimed at eliminating 'belhamels' (ringleaders) whom he considered 'uiters gevaarlik' (extremely dangerous). ${ }^{38}$

The scale of the protest and the belief that it had been organised by SASO prompted the Fort Hare University Council to appoint a commission of enquiry. Headed by the conservative Honourable Mr Justice GGA. Munnik, other members of the commission included Professor J Gerber of the Faculty of Education at Rhodes University, who was also a member of the Broederbond, and senior civil servants in the puppet states of the Ciskei and Transkei, as well as an Afrikaner educationist. ${ }^{39}$ Its terms of reference were to investigate and identify student grievances, and it met four times over the course of several months to receive evidence volunteered by students and staff.

\subsection{A divided student body: dissidents and dissenters}

Only two students came forward to offer information, and five staff members, two white and three black. The two students identified various reasons for the protest, including De Wet's treatment of students, expulsions, allegations of police harassment, the refusal of the rector to address student allegations of intimidation by lecturers, inadequate intramural facilities, poor quality of food, antagonism to apartheid, the role of Fort Hare as a 'launching pad' for Afrikaner

35 De Wet files, Students' Manifesto 7 June 1972.

36 Lamprecht files (Howard Pim Library, Alice), Lamprecht JA, Some basic trends in student unrest A report (1984), pp 61-67.

37 De Wet files, Notes on student protest 13 September 1973, Dossier on 1973 student protest.

38 Ibid.

39 Lamprecht, p. 63 
academics, deliberate failing of dissident students, the absence of an SRC and lack of representation by blacks on university bodies. ${ }^{40}$

In addition, the two students made the seemingly unusual claim that rural students, a minority on campus, were opposed to the establishment of an SRC, which was seized on as evidence of a schism in the student body. The report referred to these students as 'tuislanders' (homelanders), or inhabitants of the rural Ciskei and Transkei, and claimed that they feared being dominated by the 'noordelike gevaar' (northern danger), a reference to the more radical students from urban areas around Johannesburg. The existence of tensions between rural and urban students is borne out by interviews with former activists and dissidents who were alumni of Fort Hare. They confirmed that the children of urban working-class parents with radical views, mainly in Soweto, were identified as abaKaringes, or rebels, and that they clashed with the abaThembus, who came from more conservative rural backgrounds in the Eastern Cape. ${ }^{41}$

The commission's findings acknowledged the lack of student representation but were not in favour of the SRC being re-established and recommended that student mass meetings, the site of instigation, should be reduced to the bare minimum. ${ }^{42}$ De Wet was nonetheless set on the establishment of an intermediary student body with whom he could liaise. This body was duly reestablished in 1976, after the campus closure between August and October that followed the June Soweto student uprising. Its mandate was to cooperate with the administration and as a result, dissidents became hostile towards the SRC. Posters pinned up in dining halls accused the SRC president, WDM Memani, of being a 'goeie [good] Bantu' who was a 'diplomatic sell-out', warning that if he did not resign, there would be a violent protest. ${ }^{43}$

One of the most striking examples of student unity occurred in the aftermath of Steve Biko's death in detention by the police on 12 September 1977. When the news was released, the rector issued a statement expressing 'deep regret on the death of this Black leader ... and sympathy with students on the matter.' He agreed that a memorial service could be held outside lecturing hours at the weekend. ${ }^{44}$ The SRC demanded that all academic activities be suspended for the memorial service, posting notices that 'not a single student will attend [lectures] ... No lectures until our brothers are released', Biko dead - who's next?' ${ }^{45}$ The SRC organised an outdoor memorial service in Davidson Stadium, to which the police responded by arresting more than 1000 students for attending

$40 \quad$ Howard Pim Library, Alice, Report of Commission of Enquiry appointed by Council of the University of Fort Hare into student unrest in May 1972.

41 Massey, pp. 206-210.

42 Report of the 1972 Commission of Enquiry.

43 De Wet files, Poster, 1976.

44 Statement to the South African Broadcasting Authority 16 September 1977, in Lamprecht, p. 91.

45 Lamprecht, pp. 92-93. 
an illegal open-air gathering. On this occasion, the potential of the SRC for organising mass action from unresisting and supportive students was evident, a clear testimony to support for Black Consciousness.

However, this overwhelming solidarity did not manifest on other matters in subsequent years. In May 1980, calls by dissidents for a boycott of lectures in protest against an inferior and discriminatory educational system led to Fort Hare being closed on 19 May until 15 July. Once it reopened, the boycott resumed, leading to De Wet posting notices that those who did not attend lectures on 16 July should leave campus and forego all further academic opportunities. Students returned to class, but an uneasy calm prevailed, with notices posted by dissidents - and subsequently confiscated by campus security - threatening dissenters in an 'Open letter to all traitors. Quit and you have nothing to lose. Stick around and something your mother won't like will happen to you. Forward to a People's Government. Freedom today, degree tomorrow'. Another warned 'Dissenters shall not be tolerated for they retard the forces of progression. They shall be watched and noted by our secret service. These shall be dealt with thoroughly at a convenient time ... dissenters you are living on borrowed time'. ${ }^{46}$

The division between the dissenters and dissidents was becoming more pronounced. It had emerged that dissenters were not necessarily from the rural homelands areas or supporters of the apartheid plan to employ university graduates as civil servants in the 'homelands'. The element of fear can be considered as the most compelling reason as to why dissidents did not wish to participate actively in student protest, with repercussions ranging from expulsion to refusal of readmission and the subsequent sacrifice of a university degree, together with the prospects of future employment as a graduate. Moreover, participating in protest invariably led to being placed under surveillance by the security police, with the possibility of harassment of family members. The notion of duress, one of the four reasons for conformity offered by Femia, ${ }^{47}$ comes strongly into play.

\subsection{Campus surveillance, spies and suspicion}

The process of readmitting students after protests is seen to have been intensive, comprising scrutiny of the reasons provided by each student for having boycotted classes, accompanied by information gleaned not only from the security police but also from on-campus informers in the form of white Afrikaner lecturers and residence wardens. It has been claimed that all academic staff appointments in the 1960s were of members of the Ruiterwag, the 'youth league' of the Afrikaner

\begin{tabular}{ll}
\hline 46 & Lamprecht, pp. 101-102. \\
47 & Femia, pp. 38-43.
\end{tabular} 
Broederbond to which apartheid-era rectors Ross and De Wet belonged. ${ }^{48}$ However, black house wardens were required by the administration to assume the role of exercising control in the residences, not only through maintaining order but also by passing on information about disruptive and politically active students. For this reason, SASO had denounced them as 'mouthpieces of the administration'. ${ }^{49}$ Sub-wardens were senior students and were equally conscious of the contradictory nature of their role and the way in which it exposed them to student hostility, because,

each and every sub-warden is being watched carefully during times of unrest, and that meant that I had to exercise extra care of each and every step I take so as to save myself [...] The students consider sub-wardens as furthering the aim and objects of the university in matters that students regard as unfavourable towards them. ${ }^{50}$

Student suspicions concerning spying by wardens were confirmed after the 1973 protests when hundreds of students who had been sent off campus were not re-admitted, primarily based on information provided by wardens. De Wet's control list in the 1973 Hertoelating (Readmissions) dossier contained the names of all students who were refused readmission, with a column alongside the list for comments by the security police on the grounds for refusing readmission. Few, however, were refused readmission on the basis of information provided by the police in this instance, as nearly all were 'considered undesirable by warden', 51 indicating the extent to which some wardens were complicit in surveillance.

The pattern of expulsion and readmission was repeated during the following year. Of the total 661 students who applied for readmission in 1974, only 387 were readmitted. At the same time, 18 of the new applications for 1974 were not recommended by the Bureau of State Security (BOSS) and the Special Branch. Evidence on which the decision whether or not to readmit students was based was provided in long typed lists and came from a variety of sources on and off campus. ${ }^{52}$ Some evidence was provided in notes with the South African Police letterhead, while other letters bear no indication of the origin, but are marked 'confidential', for the attention of the rector, leading to the assumption that they were provided by informers on and off campus. Different categories provided the reasons for which readmission was refused: Category 1 listed students who had taken a 'leading role'. In this category, of the 51 who were suspended, 13 applications for readmission were refused, while some did not

48 D Harrison, The white tribe of Africa: South Africa in perspective (Berkeley: University of California Press, 1981), p. 194.

49 De Wet files, SASO Fact Sheet 3, Problems dossier, 1973.

50 De Wet files, Undated letter from sub-warden, 1973.

51 De Wet files, Hertoelating dossier, 1973.

52 De Wet files, Hertoelating dossier, 1974. 
re-apply. In Category 2, a list of students who had boycotted lectures, 97 were refused readmission. Only one student was denied readmission on political grounds, noted as being 'Leftist, anti-White, member of SASO, BPC [Black People's Convention] and Transkei Youth League', while another was noted as 'not recommended by the Bureau of State Security and Special Branch'. Others were considered undesirable because they had organised or participated in meetings on or off campus or had been rude to wardens or white civilians both on and off campus. ${ }^{53}$ Significantly, all students who belonged to SASO were listed, with their names accompanied by details of their addresses and meetings they had attended. The detail provided is indicative of the extent of state infiltration on campus and in civil society via paid informers, those coerced into providing information, like wardens, as well as apartheid zealots like some of the white Afrikaner lecturers who firmly supported the notion of an independent Ciskei state for Xhosa people. All contributed to the surveillance by the state through its official apparatus of BOSS.

Given the extent of surveillance and the extreme control exercised over the student body, it was inevitable that there was no trust. Among the students, a dissenter was not necessarily an informer and was more likely to be a student who was wary of participating for fear of expulsion. As the mistrust and division within the student body grew, mistrust crystallised in violence, manifest in physical as well as verbal attacks, as dissidents became angry and frustrated with the lack of active support from some students. Dissenters were chased out of lecture halls and the library, pelted with stones, attacked with sticks, and threatened with punishment if they failed to heed a call to boycott lectures. After the expulsions of 1972 and 1973, some letters from students requesting readmission presented as grounds for participation in the strike their fear of noncompliance in the face of the 'mass impulses' of an uncontrollable mob. ${ }^{54} \mathrm{Among}$ these, other anonymous letters to De Wet identified particular students who were accused of having masterminded the protests, pointing to the existence of students who appeared to disagree with the dissidents who were behind the strikes against the apartheid system. ${ }^{55}$ However, in the absence of firm data pointing to their beliefs, it is equally likely that they were anxious to complete their studies and did not want to waste time and sacrifice the money that had been paid by what were invariably poor families for students to attend university, a motive which is still strongly present today among students who refuse to participate in protest at Fort Hare in the post-apartheid era.

De Wet files, Hertoelating dossier, 1974.

54 De Wet files, Hertoelating dossiers 1972 and 1973.

55 Ibid. 


\subsection{The 'independent Ciskei state': consent and contestation}

During the 1970s, students had begun to organise protest under the umbrella of national movements, and even after being banned in 1979, SASO went underground and continued to align itself to the BPC. On campus, SASO was succeeded by the Azanian Students Organisation (AZASO), which collaborated with ANC-aligned organisations such as the United Democratic Front (UDF) and the Congress of South African Students (COSAS), leading to greater militancy in the student movement as it joined the call for an armed struggle to overthrow apartheid.

The 1980s were thus a decade of heightened intensity, accompanying the escalation of state repression in response to greater organised resistance and solidarity within black civil society.

1980 was also the year in which John Lamprecht succeeded De Wet as rector, and, given the escalation of organised resistance to the apartheid state and its subsidiary institutions, it was inevitable that he would be faced by more militant contestation by students. Further grounds for protest were provided by the declaration of the Ciskei as an independent republic in December 1981, headed by apartheid collaborator Lennoxlesue (Lennox) Wongama Sebe as president. ${ }^{56} \mathrm{He}$ was widely scorned and regarded as an apartheid puppet by Fort Hare students, who had boycotted the 1979 graduation in which he received an honorary doctorate in Law and who disrupted the 1982 graduation ceremony over which he was supposed to preside in 1982, forcing the university to close down. ${ }^{57}$ Incidentally, his counterpart in the Transkei, Kaiser Daliwonga Matanzima - an alumnus of Fort Hare - had been awarded the same accolade of an honorary doctorate in Law in 1974, but was not subjected to the same treatment, in all probability because Transkei only became an independent homeland, a satellite of the apartheid state, two years later.

Although Ciskei was declared an independent Xhosa state, the upper echelons of the civil service continued to be occupied by whites and the notion of independence was belied by its financial reliance on South Africa, which provided its budget. At Fort Hare, nothing changed, although there were more frequent unsolicited interventions on campus by the Ciskei security police, leading to the arrest of students - and staff - who were suspected of being involved in antiCiskei activities or belonging to banned political parties such as the ANC, PAC and the Azanian People's Organisation (AZAPO). ${ }^{58}$

But the independent Ciskei state was not totally rejected by black inhabitants of the region. Indeed, as the independent Ciskei progressively

56 CS White, The Rule of Brigadier Oupa Gqozo in Ciskei 4 March 1990 to 22 March 1994 (Master's dissertation, Rhodes University, Grahamstown, 2008), p. 19

57 Massey, pp. 284-285.

58 Lamprecht files, Notes on campus security, 1983-1985. 
expanded its bureaucracy to offer more posts as civil servants, the security of a permanent post and a salary provided a strong incentive for compliance. Those civil servants co-opted by the Ciskei state had vested interests in its existence, and part-time students on the satellite Zwelitsha campus of Fort Hare, where civil servants were registered, did not participate in the strikes that took place. Decrying student protest, these adults were anxious to complete their studies and further their careers. They disapproved of the disruption caused by students on the Alice campus to matters that affected them, such as examination timetables. An example of this sentiment is provided in a letter to Lamprecht, telling him to, 'Forget these young people - they think that they can tell everybody how to run the world ... most students are against the SRC and these stayaways. They are at university for an important purpose, to get their education'. ${ }^{59}$ Nonetheless, completion of their studies remained a compelling motive for the dissenters on the Alice campus, as evident in another letter written to Lamprecht by a student who had resisted the SRC call for all to leave in 1982, saying, "May God help and protect you ... a true, powerful and constant leader. We're in a university, not a state of chaos and confusion caused by aimless, crazy, confused elements'. ${ }^{60}$

Whilst the dissidents posted notices calling for resistance against apartheid and the university administration, some dissenters claimed that the motives of the dissidents were disingenuous and that they were in reality 'those who had written tests and failed were intimidating [us] if not forcing others to join' and that in clamping down on student protest, the rector 'really saved the "dissenters" who would be victims throughout the year'. ${ }^{61}$ The accusation that dissidents were a minority whose views did not reflect those of the majority of students, frequently levelled by the apartheid state against dissidents throughout society, was echoed by dissenters, who claimed that 'They [dissidents] make personal decisions and allege that they are mass decisions'. ${ }^{62}$

The confrontation between students and the administration continued unabated. The situation was exacerbated by the declaration by the government of a general state of emergency in 1985 in response to a groundswell of intensified resistance emanating from civil society, in particular, from black trade unions and civic groups. On the Fort Hare campus, this was manifest in the decision by non-unionised black workers who had previously remained uninvolved in protest to join striking students. Trade unions were banned in the Ciskei, but more than 1000 unskilled and semi-skilled black labourers who were employed on the campus and the adjacent Fort Hare farm demanded some form of representation. In February 1986, the council agreed to the establishment of a 'Wage-earners

59 Lamprect files, Anonymous letter signed 'Zwelitsha School Principal', 11 September 1986.

60 Lamprecht files, Anonymous letter signed 'Faithful student', 29 July 1982.

61 Lamprecht files, Anonymous letter, 3 August 1982.

62 Lamprecht files, Anonymous undated letter, 1986. 
Liaison Committee', a proposal that was rejected by workers as latent discontent emerged in an active strike that lasted for nearly three weeks in March. ${ }^{63}$

Owing to the absence of a recognised union, the strike did not achieve much. As a result, the Fort Hare Workers Union was formed, marking the beginning of involvement by organised labour in affairs on the Fort Hare campus, where until then expressions of dissent and consent respectively had been restricted to students. The first collaborative action by workers and students took the form of a stayaway and boycott of lectures on 1 May 1986 in solidarity with union mass action throughout South Africa. Those who were unwilling to join the strike were chased out of class by students wielding bricks and iron bars. Car tyres were slashed, televisions in residence lounges burned, windows broken, trucks stoned, and security guards attacked, whilst at union meetings, tyres were held aloft to warn dissenters. The police were called in and fired rubber bullets and tear gas at students, after which, following the usual pattern, students were expelled from the campus. Fort Hare was closed from 3 to 19 May, after which students were to return and write exams before campus broke for the winter recess. ${ }^{64}$

Lamprecht conceded that 'it is obvious that order is breaking down on campus' as manifest by 'intermittent violence, lawlessness, disregard for authority', ${ }^{65}$ observing that 'this year for the first time we have experienced considerable unrest among workers and I regret to say that the attitude of students as expressed through their leaders, the SRC, has been aggressive if not hostile'. ${ }^{66}$

The second semester of 1986 was to prove even more disruptive, with class boycotts starting at the end of July, shortly after students had returned to campus. Buildings were stoned and set alight, and the protests continued almost unabated until the end of August when Lamprecht wrote a letter to parents stating that unless students returned to class, disciplinary action would be taken. ${ }^{67}$ A memorandum to all staff instructed them to take attendance registers and do headcounts, and submit this information to him via faculty administrative staff.

After the subsequent return to class by some students, dissidents responded with the threat:

Some of our fellow students have taken it upon themselves to identify themselves as Lamprecht's collaborators by defying. All betrayers will feel the harshness of their deeds ... we are calling for a mass action against dissidents ... The library and lecture halls are still

\footnotetext{
63 Lamprecht files, Report to Council on student and worker stayaways, R/55/86, 2 May1986.

64 Ibid., p. 3.

65 Ibid., p.4.

66 Lamprecht files, Memorandum from Lamprecht to Fort Hare Foundation, 26 August 1986.

67 Lamprecht files, Copy of letter to parents, 25 August 1986.
} 
out of bounds. Anybody who does not abide by this condition will be declared an enemy of the student body. ${ }^{68}$

The situation in which dissenters complained to Lamprecht of victimisation whilst dissidents accused them of betrayal was complicated by the workers' stayaway. Unable to control the situation, Lamprecht obtained a court order forcing 1300 labourers back to work, and then suspended the SRC, prohibiting it from entering the campus. ${ }^{69}$ The SRC responded by distributing notices through insider contacts calling on the student body to resist attempts by management to divide them. However, some students continued attending classes, whilst others, fearing a renewed outbreak of violence similar to that in the first semester, started leaving campus. Dissidents called on students to remain on campus and to defy the call by the rector to attend class, warning that:

Failure to respond to this legitimate and well-considered call renders any defaulter as an unrehabilitated, blatant criminal deserving purification ... we realise the futility of threats devoid of serious action and therefore resolve to 1. purify homes to exterminate the virus at grassroots level 2. A happy revolutionary welcome at your respective stations. VIVA NECKLACE!!!! ASIJIKI!!!!!70

Women on their way to class were attacked by dissidents and two petrol bombs were thrown into a classroom, an incident that led to the arrest of four students. ${ }^{11}$ Despite the scale and intensity of violence throughout the campus, Lamprecht issued a statement to the press asserting that the university would not close, though he did estimate that by this time, half the student body had left the campus. ${ }^{72}$ By this time, the end of the academic year and final exams were approaching, and Lamprecht correctly estimated that the dissidents would not be able to convince the majority of students not to write their final examinations. Failing to write the final examinations and be promoted to the next academic year was too harsh a price to pay for students whose families had made enormous sacrifices for them to be able to attend university, in the hopes that they would improve the fortunes of all after obtaining a university qualification and securing a job in civil service or a profession. As indicated previously, this is

68 Lamprecht files, Notice found in Tyhali men's residence by campus security, signed 04h55 on 10 August 1986.

69 Lamprecht files, Letter to SRC president PK Mankahlana, 2 September 1986.

70 Lamprecht files, Poster, 30 September 1986. 'Necklace' refers to the method by which suspected informers were killed by placing a rubber tyre around the victim's neck, pouring petrol over it and setting it alight. 'Asijiki' is an isiXhosa expression meaning 'We are not turning back'.

71 Lamprecht files, Telex message to Director-General of Special Assignments in the Department of Education and Training, 2 October 1986.

72 Lamprecht files, Copy of press statement, 3 October 1986. 
the most prominent motive that has emerged in conversations and discussions with students at Fort Hare since the researcher joined the university in 2009.

Concerning motives for conformity, it is significant that the 767 civil servants studying part-time at Zwelitsha campus and the 250 nursing students on the Mdantsane campus near East London were unaffected by the student protest. ${ }^{73}$ This highlights both the vested interests of civil servants in completing their degrees as well as fear of the repercussions of participating, as the Sebe regime would dismiss any civil servants engaging in a strike, whilst nursing students would be barred from the professional body, the South African Nursing Association, with which they were required to register to find a job. The need for security in the form of a university qualification or job tenure appeared to have outweighed the call for political resistance, despite the threats by dissidents. Nonetheless, the pattern of protests and strikes resumed the following year, infused with the new dynamic of the solidarity that had developed between workers' unions and students.

\subsection{Regime change: national and local}

At the beginning of 1990, shortly after former president De Klerk had announced the release of Nelson Mandela from prison, Sebe was deposed by a coup and replaced by Brigadier Oupa Gqozo. ${ }^{74}$ A quick succession of strategic moves by the Democratic Staff Association - formerly the Black Staff Association - led to the ousting of the senior white administration on the Fort Hare campus. The following year, Sibusiso Bengu, an ANC stalwart, was instated as the first black vicechancellor of Fort Hare, with Oliver Tambo as the first chancellor, a clear and confident statement of intent as to how the ANC viewed the university within its greater plan after the first democratic elections, still to be held. ${ }^{75}$

However, the transition from white to black administration by no means heralded the end of student protest, which soon re-ignited as political grounds for protest gave way to economic motives behind strikes by staff and students, sometimes jointly, though more often than not by the student body alone, which have persisted sporadically until today. After joining the university in 2009, the researcher has witnessed student protest that has disrupted normal academic activities since 2011. Almost annual student strikes occur over issues revolving around student finance and government study subsidies in the form of loans, on which the vast majority of students at Fort Hare depend. The protest is as violent,

\footnotetext{
73 Lamprecht files, Telex message to Director-General of Special Assignments in the Department of Education and Training, 17 October 1986.

$74 \quad$ White, pp. 42-44.

75 Interview: Francis Wilson, Hogsback, 30 July 2011. Re: Fort Hare as a post-apartheid university in the 1990s.
} 
and damage to property far more extensive, with two building complexes on the Alice campus gutted by fire in 2017.

Ironically, the same pattern of protest followed by warnings by the university administration and ultimately campus closure occurred under Fort Hare's fourth black vice-chancellor, Dr Mvuyo Tom, in February 2013, after student protest had escalated into violence. ${ }^{76}$ A letter circulated to students required them to vacate campus and go home, detailing the conditions for their return and readmission - this, almost replicating the steps taken by the apartheid administrators. ${ }^{77}$ The difference was that the condition imposed that students sign an agreement that they would not further disrupt activities was not implemented when students returned the following week - and many had remained on campus.

The issue of finance and funding is one that resonates with almost every student on the Alice campus of Fort Hare, in an area plagued by unemployment and poverty. Yet, as in previous decades, the phenomenon of a student body divided in their views on what should be done remains. In October 2017, when protest initiated by the 'Fees must Fall' movement erupted on campuses across South Africa, many students left the Alice campus as the strike began, reluctant to become involved and fearful that they might be identified as a dissenter by striking students. Indeed, the phenomenon of coercion to participate in protests continues, and in the recent past the SRC distanced itself from a particularly destructive student strike, claiming that students had been intimidated by members of the Economic Freedom Fighters party into joining in the demands for payment of the National Student Financial Aid Scheme subsidy directly into their accounts. ${ }^{78}$ The extent of consent to the status quo - deemed 'dissent' in the apartheid era by student dissidents - and of dissidence respectively on the Fort Hare campus continues to be a significant indicator of the general condition of social malaise in South African society.

\section{CONCLUSION: REASONS FOR CONSENT.}

In examining the existence of conformity on the part of black students at the University of Fort Hare, in the sense of apparent consent to, or agreement with, the ideals and values promoted by the apartheid state, the researcher intended to illustrate reasons for the existence and behaviour of 'dissidents'. Femia's reasons for conformity elaborate on Gramsci's notion of the exercise of cultural hegemony and the mechanisms by which it is achieved within civil society,

76 Email: Dr M Tom to all staff, 12 February 2013.

77 Email: Dr M Tom to all students, 12 February 2013.

78 B Jacob, 'Pandemonium at Fort Hare', Daily Dispatch, 18 February 2019. 
enabling an understanding of the ambivalent behaviour of black students. Outright resistance of the system, advocated by dissidents and illustrated in this research by their actions, is both the spontaneous and the considered reaction of those situated themselves at the periphery of society who are subjected to exclusion and domination. However, where opportunities are perceived to result from conformity and compliance, and negative consequences to be the outcome of resistance, the choice between accepting or rejecting prospects through conforming or contesting the system is complex and produces diverse responses, as has been shown in the response of the dissenters, the less bold within the subaltern, to the apartheid state. The coercion that is generally considered exclusively as a mechanism of the state was thus evident in the responses of the dissident element of the subaltern, the more prominent element, towards the dissenters in their midst.

The most significant of the reasons proposed by Femia for conformity on the part of the dissenters, in terms of compliance with the administration of an organ of the apartheid state in the form of the University of Fort Hare, was fear of the repercussions of non-conformity, or 'acquiescence under duress'. ${ }^{79}$ Those students who assumed bold and principled anti-apartheid positions ran the risk of expulsion as well as being listed in state security files, after which they would struggle to find ordinary employment. Certainly, there is no evidence of conformity on the grounds of clear agreement with apartheid principles. In the final analysis, the basic need for security proved to be a compelling reason for conformity, one which existed not only on the part of the dissenters on the campus of the University of Fort Hare during the apartheid era but is manifest among citizens throughout the world who seek security rather than more widespread social justice.

\section{REFERENCES}

Baucom I 2001. "Frantz Fanon's radio: solidarity, diaspora, and the tactics of listening", Contemporary Literature, 42(1):15-49. https://doi.org/10.2307/1209083

Bocock, R 1986. Hegemony. Chichester: Tavistock Publications.

Chapman, RD 2016. Student resistance to apartheid at the University of Fort Hare.

Freedom now, an academic degree later. Lanham: Lexington Books.

Femia, JV 1981. Gramsci's political thought. Oxford: Clarendon Press.

Giliomee, H 2012. The last Afrikaner leaders. A supreme test of power. Cape Town: Tafelberg, 2012. 
Gramsci, A 1971. Selections from the prison notebooks of Antonio Gramsci, edited and translated by Hoare Q \& G. Nowell Smith. London: Lawrence and Wishart.

Hall, S 1986. "Gramsci's relevance for the study of race and ethnicity", Journal of Communication Inquiry, 10(2):5-27. https://doi.org/10.1177/019685998601000202

Harrison, D 1981. The white tribe of Africa: South Africa in perspective. Berkeley: University of California Press.

Jackson Lears, TJ 1985. "The concept of cultural hegemony: problems and possibilities", The American Historical Review, 90(3) June:567-593. https:// doi.org/10.2307/1860957

Johnson P 2018. "Brothers in arms: the role of Broederbond rectors in the exercise of hegemony at the University of Fort Hare 1960-1981", Politeia, 37(1):1-9. https://doi.org/10.25159/0256-8845/4372

Massey, D 2010. Under protest: the rise of student resistance at the University of Fort Hare. Pretoria: UNISA Press.

Moen, T 2006. "Reflections on the narrative approach", International Journal of Qualitative Methods, 5(4):56-69. https://doi.org/10.1177/160940690600500405

Mollis, M 1997. "The paradox of the autonomy of Argentine universities: from liberalism to regulation", in Torres CA \& A Puiggrós, eds., Latin American education: Comparative perspectives. Boulder: Westview Press.

Ngwane, Z 2001. "The long conversation': the enduring salience of nineteenthcentury missionary/colonial encounters in post-apartheid South Africa", Interventions. International Journal of Postcolonial Studies, 3(1):65-75. https://doi.org/10.1080/13698010020027029

Ngwane, Z 2001. The politics of campus and community in South Africa: an historical historiography of the University of Fort Hare, (PhD thesis, University of Chicago, Chicago).

Rassool, C 2010. "Knowledge and the politics of public pasts", Journal of African Studies, 69(1):79-101. https://doi.org/10.1080/00020181003647215

Serfontein, JHP 1979. Brotherhood of power. An exposé of the secret Afrikaner Broederbond. London: Rex Collings.

Switzer, L 1993. Power and resistance in an African society - the Ciskei Xhosa and the making of South Africa. Pietermaritzburg: University of Natal Press.

Williams, R 1980. Problems in materialism and culture. London: New Left Books. 


\section{Unpublished papers}

White, CS 2008. The Rule of Brigadier Oupa Gqozo in Ciskei 4 March 1990 to 22 March 1994. Master's dissertation, Rhodes University, Grahamstown.

Howard Pim library (University of Fort Hare)

Fort Hare Calendar 1960-1992.

\section{Reports}

1955 Report by the Duminy Commission on Student Unrest and the State of the University.

1972 Report of Commission of Enquiry appointed by Council of the University of Fort Hare into Student Unrest in May 1972.

Lamprecht, J, Some Basic Trends in Student Unrest - A Report (1984)

Unsorted rectors' and vice-chancellors' confidential files 1968-1999

De Wet files, 1968-1980.

Lamprecht files, 1981-1989.

\section{Unpublished document in De Wet files}

Du Preez, HJ, "Herinneringe van my twaalf-jarige verbintenis met die Universiteit van Fort Hare as Registrateur 1 September 1959-31.8.1971". Unpublished handwritten memoire.

\section{Interview}

Interview: Francis Wilson, Hogsback, 30 July 2011. Re: Fort Hare as a postapartheid university in the 1990s (Professor Wilson was chair of the first post-apartheid Council of the University of Fort Hare from 1990 to 1999). 